\title{
Oak pollen in the air of Poland in 2017
}

\author{
Małgorzata Puc ${ }^{1,2}$, Dorota Myszkowska ${ }^{3}$, Kazimiera Chłopek ${ }^{4}$, Elżbieta Weryszko-Chmielewska ${ }^{5}$, \\ Krystyna Piotrowska-Weryszko ${ }^{5}$, Małgorzata Malkiewicz ${ }^{6}$, Agnieszka Lipiec ${ }^{7}$, Adam Rapiejko, ${ }^{8,9}$, \\ Kornel Szczygielski ${ }^{10}$, Grzegorz Siergiejko ${ }^{11}$, Ewa M. Świebocka' ${ }^{12}$, Dariusz Jurkiewicz ${ }^{10}$, Piotr Rapiejko ${ }^{10}$, \\ Alina Stacewicz ${ }^{1,2}$ \\ ${ }^{1}$ Department of Botany and Nature Conservation, Faculty of Biology, University of Szczecin, Poland \\ ${ }^{2}$ Molecular Biology and Biotechnology Centre, Faculty of Biology, University of Szczecin, Poland \\ ${ }^{3}$ Department of Clinical and Environmental Allergology, Jagiellonian University Medical College, Cracow, Poland \\ ${ }^{4}$ Faculty of Earth Sciences, University of Silesia, Sosnowiec, Poland \\ ${ }^{5}$ Department of Botany, University of Life Sciences, Lublin, Poland \\ ${ }^{6}$ Department of Paleobotany, Institute of Geological Sciences, University of Wroclaw, Poland \\ ${ }^{7}$ Department of Prevention of Environmental Hazards and Allergology, Medical University of Warsaw, Poland \\ ${ }^{8}$ Oxford Archaeology Ltd., Oxford, England \\ ${ }^{9}$ Allergen Research Center Ltd., Warsaw, Poland \\ ${ }^{10}$ Department of Otolaryngology with Division of Cranio-Maxillo-Facial Surgery, Military Institute of Medicine, \\ Warsaw, Poland \\ ${ }^{11}$ Pediatrics, Gastroenterology and Allergology Department, University Children Hospital, \\ Medical University of Bialystok, Poland \\ ${ }^{12}$ Pediatrics, Gastroenterology and Allergology Department, University Children Hospital, \\ Medical University of Bialystok, Poland
}

\begin{abstract}
The aim of the study was to compare the pollen season of oak in the cities of Bialystok, Bydgoszcz, Cracow, Katowice, Piotrkow Trybunalski, Lublin, Olsztyn, Opole, Szczecin, Warsaw, Wroclaw and Zielona Gora in 2017. Measurements were performed by the volumetric method (Hirst type pollen sampler). Seasonal Pollen Index (SPI) was estimated as the sum of daily average pollen concentrations in the given season. Pollen season was defined as the period in which $98 \%$ of the annual total catch occurred. The pollen season of oak started first in Szczecin, on the $1^{\text {st }}$ April, and lasted till the end of May. At the latest pollen season ended in Olsztyn on the $1^{\text {st }}$ June. However, in the most of other cities the season lasted till the end of May. The differences of pollen seasons duration were considerables from 28 to 56 days. The highest, record airborne concentration of 342 pollen grains/ $\mathrm{m}^{3}$ was noted in Warsaw on the $17^{\text {th }}$ May. The maximum values of seasonal pollen count occurred between of $11^{\text {th }}$ and $20^{\text {th }}$ May. The highest oak pollen allergen hazard occurred in 2017 in Piotrkow Trybunalski, Lublin and Warsaw.
\end{abstract}

Key words: allergens, pollen count, oak (Quercus), linear trend, 2017

or a person allergic to Fagales (e.g. Quercus) pollen, there is a relatively long period of discomfort each year. Induced by a sudden and intense pollination, clinical manifestations are severe, with and adverse impact on asthmatic patients [1].

Three species of oak occur in central Europe, Quercus robur L. (pendunculate oak), Q. petrea (Matt.) Liebl. (sessile oak) and Q. pubescens Willd. (pubescent oak). Q. robur can tolerate urban conditions quite successfully. It often forms hybrids with $Q$. petrea. Oak is monoecious, wind-pollinated tree. It does not produce as much pollen as pine-tree. However, one well developed crown of oak can yield more than 100 million pollen grains. The amount of pollen production and distance of dispersal depend on whether the tree is growing in dense forest or as an isolated tree, growing 
in an open area. It is commonly accepted that its relative representations in percentage pollen diagrams reflect more or less its actual proportional frequency in surrounding forest communities [2].

The oak pollen analysed in this paper comes from areas with high anthropopression and urbanization. Traffic-related pollutants such as ozone, particulate matter less than 10 micrometers have been linked to allergic responses, asthma exacerbation and lung development, in children and adults, especially with pollen allergen contact [3].

Clinical symptoms of allergic disease are connected with the concentration of aeroallergen, e.g. oak pollen allergen the subjects are exposed to. The threshold value for clinical symptoms for Quercus pollen grains for the many of sensitised patients is visible during exposure to the concentration of 16 pollen grains in $1 \mathrm{~m}^{3}$ of air, while the clinical symptoms for the most of sensitised patients is visible during exposure to the concentration of 91 pollen grains in $1 \mathrm{~m}^{3}$ of air [4].

Aim

The aim of the study was to compare the oak pollen concentrations in the air of Bialystok, Bydgoszcz, Cracow, Katowice, Piotrkow Trybunalski, Lublin, Olsztyn, Opole, Szczecin, Warsaw, Wroclaw, Zielona Gora in 2017.

\section{Material and method}

Measurements of bioaerosols were carried out in the northern cities of Poland, in Bialystok, Bydgoszcz, Cracow, Katowice, Piotrkow Trybunalski, Lu- blin, Olsztyn, Opole, Szczecin, Warsaw, Wroclaw, Zielona Gora in 2017.

Measurements were performed by the volumetric method. The used devices, which are recommended by the IAA (International Association for Aerobiology), take air samples (Burkard and Lanzoni as the Hirst type pollen sampler) in volumes corresponding to average human respiratory parameters.

The duration of the pollen season was determined by the $98 \%$ method [5], assuming that the onset and end of the season were days with recorded $1 \%$ and $99 \%$ of the annual total of pollen grains, respectively.

The total pollen count over this period was expressed by the SPI (Seasonal Pollen Index).

On the basis of literature data, the number of days with concentrations of the pollen of the Hazel genus exceeding the threshold values at which the consecutive allergy symptoms develop were determined (tab. 1) [4].

\section{Results and discussion}

The symptoms of respiratory allergic diseases is very common especially in developed areas. High oak pollen concentrations occur from the beginning of April to the end of May and with increased levels of air pollutants such as $\mathrm{SO}_{2}, \mathrm{NO}_{2}, \mathrm{CO}_{2}, \mathrm{O}_{3}$ in big cities can aggravate the symptoms of allergies in patients. Also the morphological and biochemical changes within the pollen grain caused by air pollutants [6] can cause a more frequent occurrence of inhalant allergies or can lead to genetic mutations and thus to changes in allergenic protein's secondary structure [7].

In 2017 oak pollen season started between $1^{\text {st }}$ and $26^{\text {th }}$ April and lasted until the beginning of June. In

Table 1. Characteristics of oak pollen season in 2017.

\begin{tabular}{|c|c|c|c|c|c|c|c|c|c|c|c|c|}
\hline $\begin{array}{l}\text { Features of } \\
\text { pollen season }\end{array}$ & Bialystok & Bydgoszcz & Cracow & Katowice & $\begin{array}{c}\text { Piotrkow } \\
\text { Trybunalski }\end{array}$ & Lublin & Olsztyn & Opole & Szczecin & Warsaw & Wroclaw & $\begin{array}{c}\text { Zielona } \\
\text { Gora }\end{array}$ \\
\hline $\begin{array}{l}\text { Duration of } \\
\text { pollen season } \\
\text { (number of days) }\end{array}$ & $\begin{array}{l}7 \mathrm{IV}-28 \mathrm{~V} \\
(52)\end{array}$ & $\begin{array}{l}7 \text { IV-29 V } \\
(53)\end{array}$ & $\begin{array}{l}15 \mathrm{IV} \\
-27 \mathrm{~V} \\
(43)\end{array}$ & $\begin{array}{l}12 \text { IV } \\
-9 \mathrm{~V} \\
(28)\end{array}$ & $\begin{array}{l}26 \text { IV-27 V } \\
(32)\end{array}$ & $\begin{array}{l}21 \text { IV } \\
-30 \mathrm{~V} \\
(40)\end{array}$ & $\begin{array}{l}15 \mathrm{IV} \\
-1 \mathrm{VI} \\
(48)\end{array}$ & $\begin{array}{l}4 \text { IV } \\
-25 \mathrm{~V} \\
(52)\end{array}$ & $\begin{array}{l}1 \text { IV } \\
-26 \mathrm{~V} \\
(56)\end{array}$ & $\begin{array}{l}22 \text { IV } \\
-27 \mathrm{~V} \\
(36)\end{array}$ & $\begin{array}{l}5 \text { IV } \\
-19 \mathrm{~V} \\
(45)\end{array}$ & $\begin{array}{l}\text { 9 IV } \\
-25 \mathrm{~V} \\
(47)\end{array}$ \\
\hline $\begin{array}{l}\text { Seasonal Pollen } \\
\text { Index (total) }\end{array}$ & 227 & 847 & 596 & 120 & 1948 & 2643 & 942 & 1877 & 735 & 2754 & 1888 & 1776 \\
\hline $\begin{array}{l}\text { Peak value and } \\
\text { peak date }\end{array}$ & $\begin{array}{l}35 \\
(20 \mathrm{~V})\end{array}$ & $\begin{array}{l}53 \\
(12 \mathrm{~V})\end{array}$ & $\begin{array}{l}65 \\
(15 \mathrm{~V})\end{array}$ & $\begin{array}{l}16 \\
(22 \mathrm{IV})\end{array}$ & $\begin{array}{l}254 \\
(20 \mathrm{~V})\end{array}$ & $\begin{array}{l}245 \\
(11 \mathrm{~V})\end{array}$ & $\begin{array}{l}89 \\
(17 \mathrm{~V})\end{array}$ & $\begin{array}{l}132 \\
(12 \mathrm{~V})\end{array}$ & $\begin{array}{l}92 \\
(15 \mathrm{~V})\end{array}$ & $\begin{array}{l}342 \\
(17 \mathrm{~V})\end{array}$ & $\begin{array}{l}207 \\
(12 \mathrm{~V})\end{array}$ & $\begin{array}{l}154 \\
(12 \mathrm{~V})\end{array}$ \\
\hline $\begin{array}{l}\text { Days } \geq 16 \mathrm{~g} / \mathrm{m}^{3} \\
{[4]^{*}}\end{array}$ & 3 & 24 & 16 & 1 & 16 & 23 & 23 & 16 & 19 & 20 & 28 & 31 \\
\hline $\begin{array}{l}\text { Days } \geq 91 \mathrm{~g} / \mathrm{m}^{3} \\
{[4]^{\star *}}\end{array}$ & 0 & 0 & 0 & 0 & 10 & 10 & 0 & 5 & 1 & 12 & 4 & 3 \\
\hline
\end{tabular}

* symptoms present in many patients; ** symptoms present in most patients. 
2015 the Quercus pollen season in most Poland's cities started the earliest on $16^{\text {th }}$ April in Sosnowiec [8], i.e. 2 weeks earlier than in 2017. The oak pollen season started the earliest in Szczecin. However, the early appearance of Quercus pollen in the air is due to the differences in blooming of various species of oak (tab. 1, fig. 1-6). $Q$. petrea blooms about 2 weeks earlier than Q. robur [9], which influences the multi-phasedness of the oak pollen season. In Szczecin many of the above species are represented, as well as $Q$. rubra, Q. cerris, Q. coccinea, Q. macrocarpa and others [10]. If pollen allergy thresholds are exceeded, then overlapping of these phases, variation in the start date of the season and the intensity are also important. Analysis of the onset of pollen season in Szczecin in 18 years showed a tendency to delay the beginning of the season by 11 days (fig. 7).

The highest daily pollen count of Quercus was noted in 2017 in Warsaw on $17^{\text {th }}$ April (342 g/ $\mathrm{m}^{3}$ ) (tab. 1, fig. 1-6) and the highest annual sum of oak pollen grains (SPI) was observed also in Warsaw, a similar value was noted in Lublin; in other cities SPI value was much lower (the lowest value in Katowice 120). In 2015 the maximum daily concentration was observed between $24^{\text {th }}$ April and $6^{\text {th }}$ May [8].

The highest Quercus pollen allergen hazard occurred (above $91 \mathrm{~g} / \mathrm{m}^{3}$ ) in Warsaw, Piotrkow Trybunalski and Lublin (10-12 days). In other cities that value did not exceed 4 days. The comparison of oak pollen seasons in previous years revealed that in 2015 [8]

Figure 1. Oak pollen count in Bialystok and Bydgoszcz in 2017.

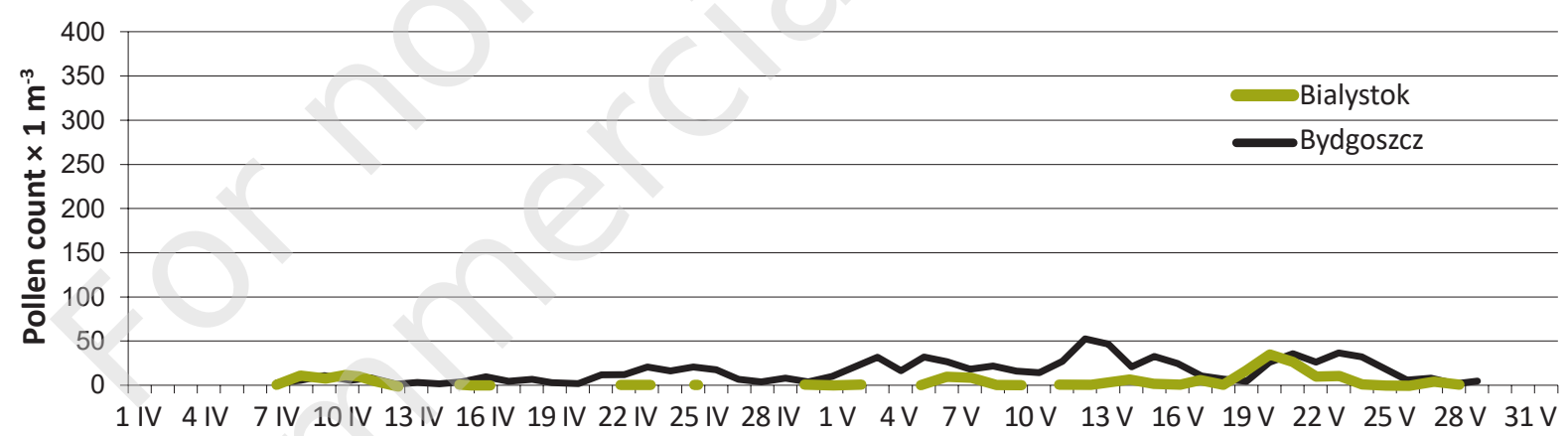

Figure 2. Oak pollen count in Cracow and Katowice in 2017.

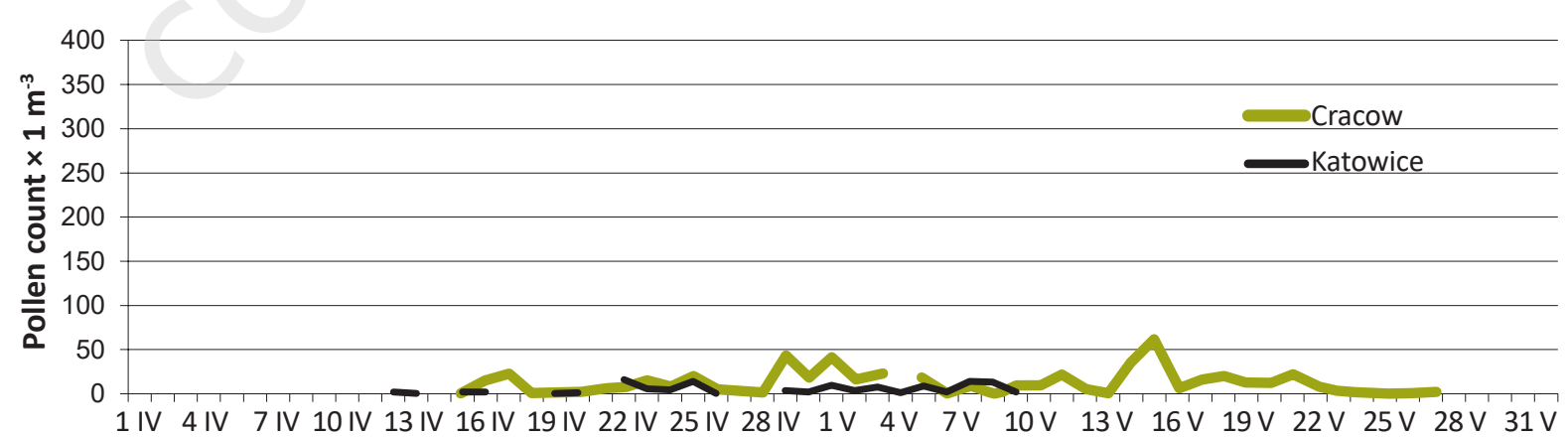

Figure 3. Oak pollen count in Piotrkow Trybunalski and Lublin in 2017.

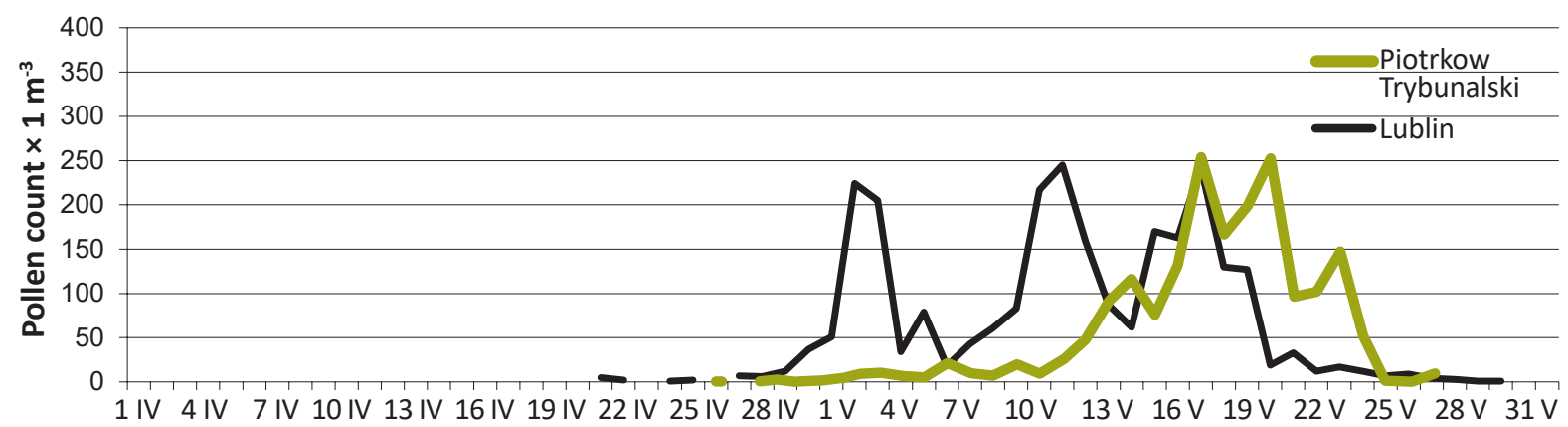


Figure 4. Oak pollen count in Olsztyn and Opole in 2017.

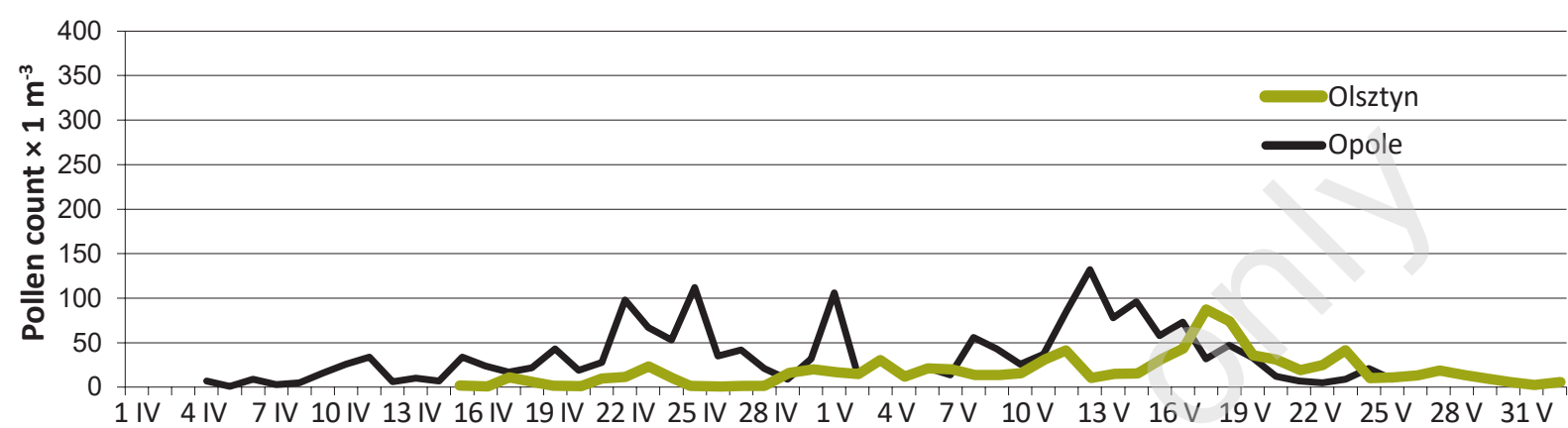

Figure 5. Oak pollen count in Szczecin and Warsaw in 2017.

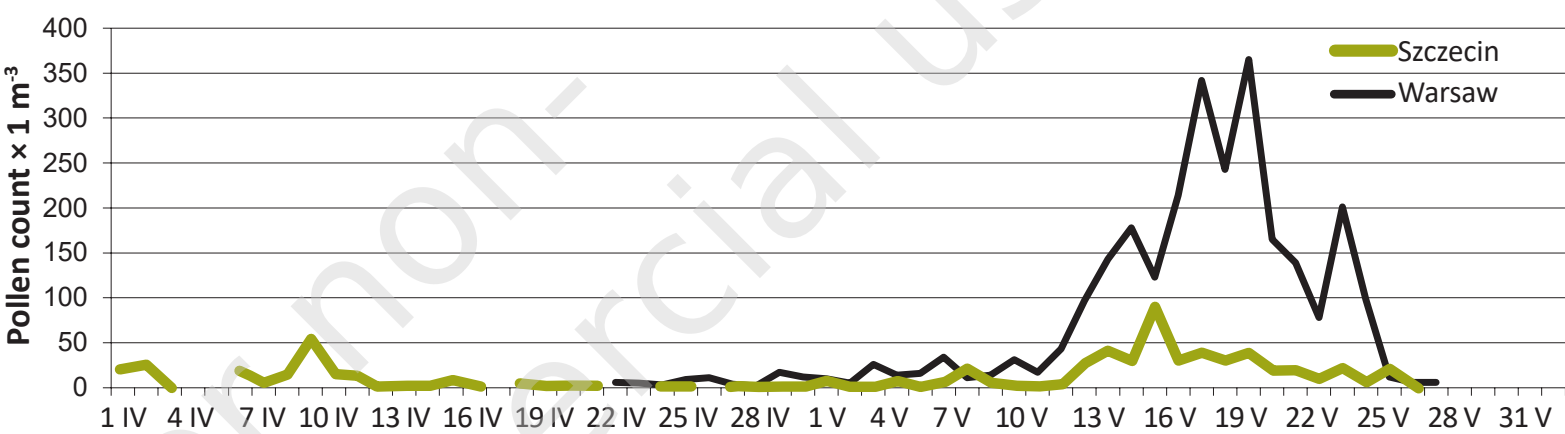

Figure 6. Oak pollen count in Wroclaw and Zielona Gora in 2017.

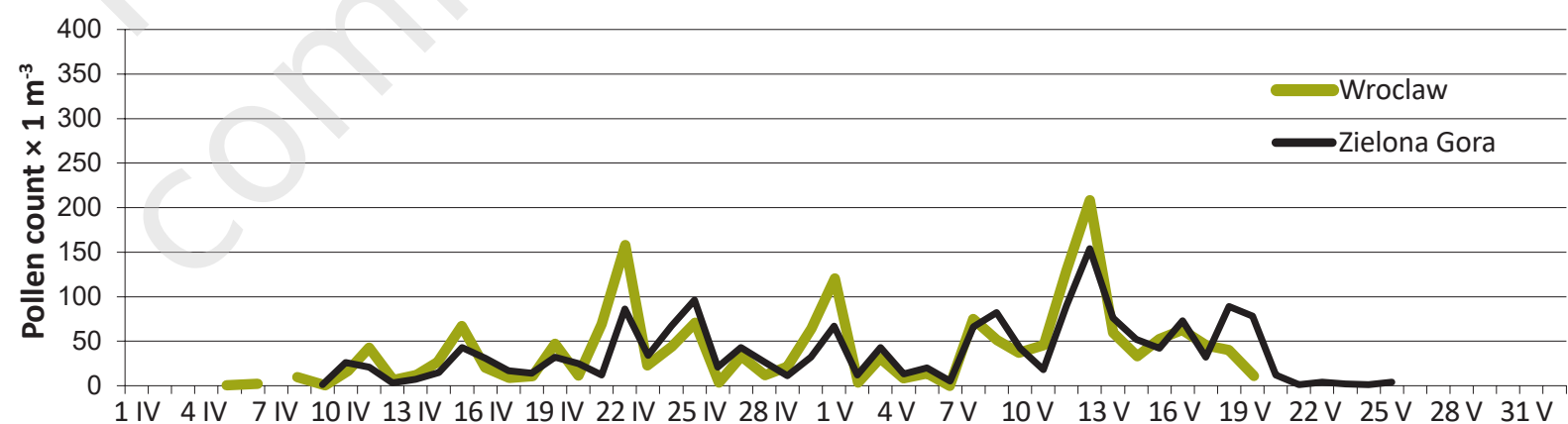

Figure 7. Linear trend of the beginning of oak pollen season in Szczecin in the years 2000-2017.

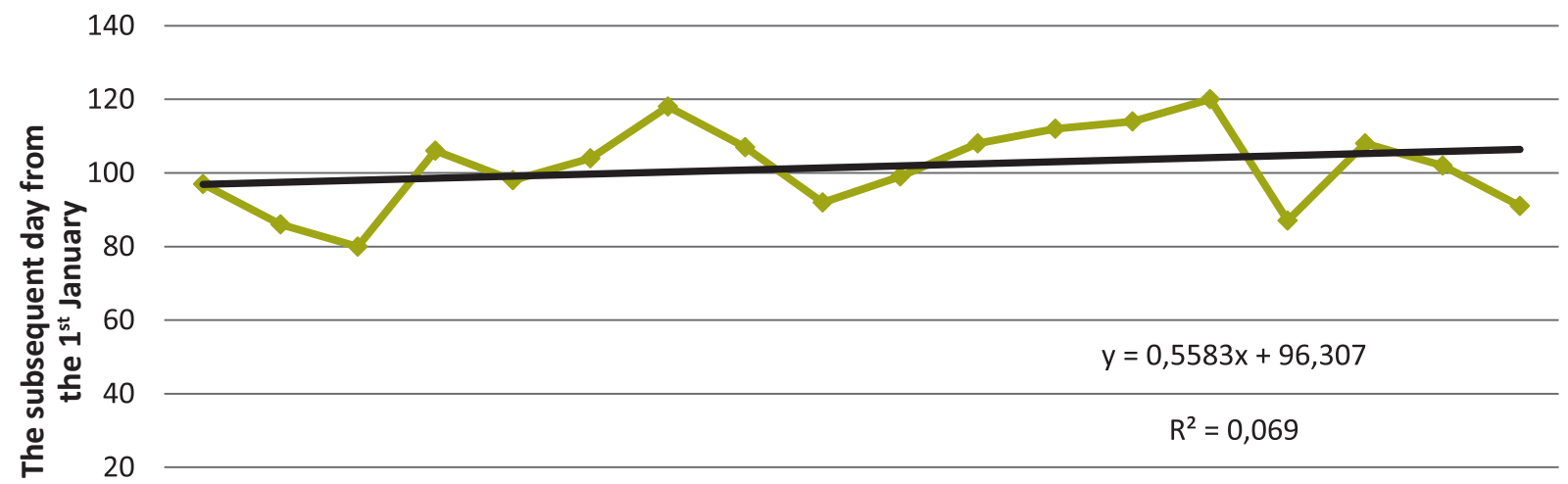

200020012002200320042005200620072008200920102011201220132014201520162017 
oak pollen concentrations in Wroclaw was also very high $\left(364 \mathrm{~g} / \mathrm{m}^{3}\right)$, however the number of days with the highest allergen hazard did not exceed 8 days (in Piotrkow Trybunalski).

\section{Conclusions}

Oak pollen season in most cities was $40-56$ days long and was characterized by very different total annual pollen SPI (from 227 to 2754).

The start of Quercus pollen season in 2017 occurred in the beginning of April in Szczecin; and even at the end of April in Piotrkow Trybunalski.

The highest oak pollen allergen hazard occurred in 2017 in Piotrkow Trybunalski, Lublin and Warsaw. The period with pollen counts exceeding the threshold value $\left(\geq 91 \mathrm{~g} / \mathrm{m}^{3}\right)$ lasted as long as 10 and 12 days.

The concentration of oak pollen is higher when there are many local sources of pollen with many species within the genus Quercus.

\section{References:}

1. D'Amato G, Spieksma FT, Bonini S (ed.). Allergenic Pollen and Pollinosis in Europe. 1991, Blackwell Scientific Publ.

2. Ralska-Jasiewiczowa M (ed.). Late Glacial and Holocene history of vegetation in Poland based on isopollen maps. Wyd. Instytutu Botaniki UJ, Cracow 2004.

3. Saxon A, Diaz-Sanchez D. Air pollution and allergy: you are what you breathe. Nature Immunology 2005, 6(3): 223-226.

4. Burge HA. Monitoring for airborne allergens. Ann. Allergy 1992, 69: 9-21.

5. Emberlin $J$, Savage $M$, Woodman $R$. Annual variations in the concentrations of Betula pollen in the Lon- don area 1961-1990. Grana 1993, 32: 359-363, DOI: 10.1080/00173139309428965.

6. Todea D, Suatean I, Coman AC et al. The effect of climate change and air pollution on allergenic potential of pollens. Notulae Botanicae Horti Agrobotanici Cluj-Napoca 2013, 41(2): 646-650

7. Depciuch J, Kasprzyk I, Sadik O et al. FTIR analysis of molecular composition changes in hazel pollen from unpolluted and urbanized areas. Aerobiologia 2017, 33: 1-12. DOI: 10.1007/s10453-016-9445-3.

8. Lipiec A, Puc M, Malkiewicz M et al. The analysis of oak pollen count in selected Polish cities in 2015. Alergoprofil 2015, 11(3): 45-49.

9. Rutkowski L. Klucz do oznaczania roślin naczyniowych Polski niżowej. Wyd. Naukowe PWN, Warszawa 2006.

10. Stachak A, Grinn U, Haas-Nogal M et al. Zieleń Szczecina. Oficyna 2000.

Authors' contributions:

Puc M: 40\%; Myszkowska D: 10\%; Rapiejko P: $10 \%$; Stacewicz A: $10 \%$ and other Authors: $3 \%$ each.

Conflict of interests:

The authors declare that they have no competing interests.

Financial support:

Does not occur

Ethics:

The contents presented in this paper are compatible with the rules the Declaration of Helsinki, EU directives and standardized requirements for medical journals.

Research in Bialystok, Bydgoszcz, Olsztyn, Piotrkow Trybunalski, Wroclaw, Zielona Gora and Warsaw funded by Allergen Research Center Ltd. (Ośrodek Badania Alergenów Środowiskowych Sp. z 0.0.).

\section{Corresponding author:}

\section{Malgorzata Puc, PhD, Ass. Prof}

Department of Botany and Nature Conservation, Faculty of Biology, University of Szczecin 71-412 Szczecin, Z. Felczaka 3c street e-mail: mapuc@univ.szczecin.pl 